\title{
Pineal cysts without hydrocephalus: Microsurgical resection via an infratentorial-supracerebellar approach - Surgical strategies, complications and their avoidance - How we do it.
}

Steffen Fleck ( $\nabla$ sfleck@uni-greifswald.de )

Universitatsmedizin Greifswald https://orcid.org/0000-0002-2465-2893

\author{
Ahmed El Damaty \\ Ina Lange \\ Marc Matthes \\ Sascha Marx \\ Ehab El Rafaee \\ Jörg Baldauf \\ Henry WS Schroeder
}

\section{Research Article}

Keywords:

Posted Date: March 3rd, 2022

DOI: https://doi.org/10.21203/rs.3.rs-1381665/v1

License: (c) (i) This work is licensed under a Creative Commons Attribution 4.0 International License. Read Full License 


\section{Abstract}

\section{Introduction}

Indications for surgery of pineal cysts without ventriculomegaly are still under debate. In view of the limited data for pineal cyst resection in the absence of hydrocephalus, and the potential risk of this approach, we have analysed our patient cohort focussing on strategies to avoid complications according to our experience in a series of 73 pineal cyst patients.

\section{Methods}

From 2003 to 2015, we reviewed our database retrospectively for all patients operated on a pineal cyst. Furthermore, we prospectively collected patients from 2016 to 2020. In summary, 73 patients with a pineal cyst were treated surgically between 2003 and 2020. All patients were operated on via a microscopic supracerebellar-infratentorial (SCIT) approach. The mean follow-up period was 26.6 months (range: 6-139 months).

\section{Results}

73 patients underwent surgery for a pineal cyst. An absence of enlarged ventricles was documented in 62 patients (51 female, 11 male, mean age 27.67 yrs). Main presenting symptoms included headache, visual disturbances, dizziness/vertigo, nausea/emesis, sleep disturbances. Complete cyst resection was achieved in 59/62 patients. 55 of 62 (89\%) patients improved after surgery with good or even excellent results according to the Chicago Chiari Outcome Scale, with complete or partial resolution of the leading symptoms.

\section{Conclusion}

Pineal cysts resection might be an indication in certain patients for surgery even in the absence of ventriculomegaly. The high percentage of postoperative resolution of quality-of-life impairing symptoms in our series seems to justify surgery. Preoperatively, other causes of the leading symptoms have to be excluded.

\section{Introduction}

Magnetic resonance imaging (MRI) reveals pineal cysts in 1.8 to $4.3 \%$ of healthy subjects ${ }^{18,19,27,40}$. Autopsy studies suggest that up to $40 \%$ of the general population harbors a pineal cyst $20,21,43$. Although usually asymptomatic, pineal cysts can grow leading to mass effect on the surrounding structures (tectum, aqueduct, venous structures) and thereby necessitate treatment $6,14,16,19,22,24,28,32,33,42,44-46$.

Due to the high prevalence of pineal cysts with nonspecific symptoms, the discussion about the relation of the symptoms to the pineal cysts is ongoing 3,9,15,21,41. Nowadays, the management of patients who present only with headache but without neurological symptoms and a pineal cyst in the absence of hydrocephalus is not clearly defined. Some authors suggest that in the absence of obstructive hydrocephalus or tectal compression, symptoms should not be attributed to the pineal cyst and these patients should be managed conservatively ${ }^{3}$. Otherwise, it is postulated that pineal cyst may cause intermittent obstruction of the Sylvian aqueduct or compression of critical neural structures, making resection reasonable after thorough preoperative examination 8,19,21,24,31,36,47,49 37. Pineal abnormalities may play a critical role in sleep disturbances and even in major depressive disorders ${ }^{51}$. Due to ethical reasons, a randomized controlled trial will be not acceptable to clarify more insights in the role of surgical therapy for pineal cysts associated with "unspecific symptoms". Large prospective studies are limited, whereas prospective data collection of case series seems to be a proper tool ${ }^{26}$.

Therefore, we present our experience with the resection of pineal cysts in the absence of ventriculomegaly to confirm the indication for surgery and to report on complications and their avoidance. 


\section{Patients And Methods}

The study protocol has been approved by the local ethics committee. It includes a retrospective review of prospectively collected data and records of the patients who underwent a surgery for a pineal cyst without ventriculomegaly from 2003 to 2015 as well as a follow-up clinical examination. All subjects gave written informed consent. Furthermore, we collected data prospectively from 2016 to 2020 . We studied our consecutive case series from a single academic institution regarding demographic data, presenting symptoms, radiological characteristics, surgical approach, extent of resection, perioperative complications, as well as clinical and radiological follow-up. Other possible and obvious causes of the leading symptoms had been ruled out by consultations (e.g. ophthalmology, neurology, neuropediatrics, internal medicine, psychiatry, and/or psychology). The investigations were carried out in the referring center. Otherwise, we completed the missing investigations in our institution within a structured preoperative work-up. Intracranial pressure (ICP) monitoring was not performed prior to surgery.

In view of the still vague indication for surgery in pineal cysts without hydrocephalus, we discussed extensively the decision with our patients individually. Typical symptoms considered during decision-making were headache associated with symptoms denoting elevated intracranial pressure, i.e. nausea and/or emesis, visual disturbance (blurring of vision, upward gaze palsy) resulting from possible tectal compression. Other, more unrelated symptoms were sometimes described by patients (see Table 1 for details). 
Table 1

List of patients

\begin{tabular}{|c|c|c|c|c|c|c|c|c|}
\hline $\begin{array}{l}\text { Absolute } \\
\text { Nr. }\end{array}$ & $\begin{array}{l}\text { Age at } \\
\text { surgery } \\
\text { /Gender }\end{array}$ & $\begin{array}{l}\text { Symptoms / } \\
\text { Signs }\end{array}$ & $\begin{array}{l}\text { Type } \\
\text { of } \\
\text { surgery }\end{array}$ & $\begin{array}{l}\text { Position } \\
\text { in } \\
\text { surgery }\end{array}$ & $\begin{array}{l}\text { Largest } \\
\text { cyst } \\
\text { diameter } \\
\text { in } \mathrm{mm}\end{array}$ & Complications & Outcome & $\operatorname{ccos}$ \\
\hline 1 & $33 \mathrm{~F}$ & Headache & MSR & SS & 11 & Pneumothorax & $\begin{array}{l}\text { No } \\
\text { complaints }\end{array}$ & 16 \\
\hline 2 & $20 \mathrm{~F}$ & Headache & MTR & SS & 11 & - & $\begin{array}{l}\text { No } \\
\text { complaints }\end{array}$ & 16 \\
\hline 3 & $19 \mathrm{~F}$ & $\begin{array}{l}\text { Headache, } \\
\text { nausea, emesis }\end{array}$ & MTR & SS & 19 & - & $\begin{array}{l}\text { Marked } \\
\text { improvement } \\
\text { but new } \\
\text { concentration } \\
\text { and memory } \\
\text { deficits }\end{array}$ & 12 \\
\hline 4 & $47 \mathrm{~F}$ & $\begin{array}{l}\text { Headache, } \\
\text { nausea, emesis, } \\
\text { dizziness }\end{array}$ & MTR & SS & 19 & $\begin{array}{l}\text { Air embolism, } \\
\text { diplopia after } \\
\text { surgery }\end{array}$ & $\begin{array}{l}\text { Marked } \\
\text { improvement, } \\
\text { diplopia } \\
\text { improved } \\
\text { later }\end{array}$ & 12 \\
\hline 5 & $27 \mathrm{~F}$ & Headache & MTR & SS & 19 & - & $\begin{array}{l}\text { Headache } \\
\text { improved but } \\
\text { new } \\
\text { behavioral } \\
\text { changes }\end{array}$ & 13 \\
\hline 6 & $26 \mathrm{~F}$ & Headache & MTR & $\mathrm{CC}$ & 19 & - & $\begin{array}{l}\text { No } \\
\text { complaints }\end{array}$ & 16 \\
\hline 7 & $24 \mathrm{~F}$ & $\begin{array}{l}\text { Headache, } \\
\text { concentration } \\
\text { deficit }\end{array}$ & MTR & SS & 16 & - & $\begin{array}{l}\text { No } \\
\text { complaints }\end{array}$ & 16 \\
\hline 8 & $25 \mathrm{~F}$ & $\begin{array}{l}\text { Headache, } \\
\text { dizziness, } \\
\text { ataxia }\end{array}$ & MTR & SS & 18 & - & $\begin{array}{l}\text { No } \\
\text { complaints }\end{array}$ & 16 \\
\hline 9 & $20 \mathrm{~F}$ & $\begin{array}{l}\text { Headache, } \\
\text { nausea, } \\
\text { dizziness, } \\
\text { blurred vision, } \\
\text { concentration } \\
\text { deficits }\end{array}$ & MTR & SS & 15 & - & $\begin{array}{l}\text { No } \\
\text { complaints }\end{array}$ & 16 \\
\hline 10 & $4 \mathrm{~F}$ & $\begin{array}{l}\text { Headache, } \\
\text { vomiting }\end{array}$ & MTR & $\mathrm{CC}$ & 11 & - & $\begin{array}{l}\text { No } \\
\text { complaints }\end{array}$ & 16 \\
\hline 11 & $6 \mathrm{M}$ & $\begin{array}{l}\text { Headache, } \\
\text { emesis }\end{array}$ & MSR & $\mathrm{CC}$ & 9 & - & $\begin{array}{l}\text { No } \\
\text { complaints }\end{array}$ & 16 \\
\hline 12 & $31 \mathrm{~F}$ & $\begin{array}{l}\text { Headache, } \\
\text { nausea, } \\
\text { diplopia }\end{array}$ & MTR & SS & 11 & - & $\begin{array}{l}\text { No } \\
\text { complaints }\end{array}$ & 16 \\
\hline
\end{tabular}

Abbreviations:

MTR: microsurgical total resection, MSR: microsurgical subtotal resection, SS: semi-sitting, CC: Concord, CCOS: Chicago Chiari Outcome Score 


\begin{tabular}{|c|c|c|c|c|c|c|c|c|}
\hline $\begin{array}{l}\text { Absolute } \\
\text { Nr. }\end{array}$ & $\begin{array}{l}\text { Age at } \\
\text { surgery } \\
\text { /Gender }\end{array}$ & $\begin{array}{l}\text { Symptoms / } \\
\text { Signs }\end{array}$ & $\begin{array}{l}\text { Type } \\
\text { of } \\
\text { surgery }\end{array}$ & $\begin{array}{l}\text { Position } \\
\text { in } \\
\text { surgery }\end{array}$ & $\begin{array}{l}\text { Largest } \\
\text { cyst } \\
\text { diameter } \\
\text { in } \mathrm{mm}\end{array}$ & Complications & Outcome & $\operatorname{ccos}$ \\
\hline 13 & $26 \mathrm{~F}$ & $\begin{array}{l}\text { Headache, } \\
\text { dizziness, } \\
\text { diplopia }\end{array}$ & MTR & SS & 16 & $\begin{array}{l}\text { Developed } \\
\text { diplopia after } \\
\text { surgery }\end{array}$ & $\begin{array}{l}\text { Headache, } \\
\text { dizziness and } \\
\text { diplopia } \\
\text { improved } \\
\text { markedly } \\
\text { later }\end{array}$ & 13 \\
\hline 14 & $26 \mathrm{~F}$ & $\begin{array}{l}\text { Headache, } \\
\text { nausea, sleep } \\
\text { disorder, ataxia }\end{array}$ & MTR & SS & 19 & $\begin{array}{l}\text { Developed } \\
\text { generalized } \\
\text { malaise after } \\
\text { surgery }\end{array}$ & $\begin{array}{l}\text { Headache, } \\
\text { nausea and } \\
\text { ataxia } \\
\text { improved } \\
\text { markedly but } \\
\text { did not } \\
\text { resolve }\end{array}$ & 12 \\
\hline 15 & $28 \mathrm{~F}$ & $\begin{array}{l}\text { Headache, } \\
\text { nausea, blurred } \\
\text { vision, tinnitus }\end{array}$ & MTR & SS & 11 & $\begin{array}{l}\text { Peripheral nerve } \\
\text { lesion due to } \\
\text { positioning }\end{array}$ & $\begin{array}{l}\text { No } \\
\text { complaints }\end{array}$ & 16 \\
\hline 16 & $26 \mathrm{~F}$ & $\begin{array}{l}\text { Headache, } \\
\text { nausea, blurred } \\
\text { vision }\end{array}$ & MTR & SS & 16 & - & $\begin{array}{l}\text { No } \\
\text { complaints }\end{array}$ & 16 \\
\hline 17 & $13 \mathrm{~F}$ & $\begin{array}{l}\text { Nausea, } \\
\text { emesis, } \\
\text { diplopia }\end{array}$ & MTR & SS & 10 & $\begin{array}{l}\text { Diplopia } \\
\text { worsened after } \\
\text { surgery }\end{array}$ & $\begin{array}{l}\text { Mild } \\
\text { headache, } \\
\text { diplopia } \\
\text { slightly } \\
\text { improved }\end{array}$ & 13 \\
\hline 18 & $10 \mathrm{M}$ & $\begin{array}{l}\text { Headache, } \\
\text { nausea, emesis }\end{array}$ & MTR & $\mathrm{CC}$ & 11 & - & $\begin{array}{l}\text { No } \\
\text { complaints }\end{array}$ & 16 \\
\hline 19 & $7 F$ & Headache & MTR & SS & 11 & - & $\begin{array}{l}\text { Headache } \\
\text { improved } \\
\text { markedly but } \\
\text { developed a } \\
\text { sleep } \\
\text { disorder }\end{array}$ & 12 \\
\hline 20 & $38 \mathrm{~F}$ & $\begin{array}{l}\text { Headache, } \\
\text { dizziness, } \\
\text { nausea, } \\
\text { concentration } \\
\text { deficit }\end{array}$ & MTR & SS & 13 & $\begin{array}{l}\text { Blurred vision } \\
\text { after surgery }\end{array}$ & $\begin{array}{l}\text { Headache, } \\
\text { nausea, } \\
\text { dizziness } \\
\text { improved } \\
\text { markedly, } \\
\text { and blurred } \\
\text { vision } \\
\text { resolved, } \\
\text { concentration } \\
\text { deficit } \\
\text { remained } \\
\text { unchanged }\end{array}$ & 15 \\
\hline
\end{tabular}

Abbreviations:

MTR: microsurgical total resection, MSR: microsurgical subtotal resection, SS: semi-sitting, CC: Concord, CCOS: Chicago Chiari Outcome Score 


\begin{tabular}{|c|c|c|c|c|c|c|c|c|}
\hline $\begin{array}{l}\text { Absolute } \\
\text { Nr. }\end{array}$ & $\begin{array}{l}\text { Age at } \\
\text { surgery } \\
\text { /Gender }\end{array}$ & $\begin{array}{l}\text { Symptoms / } \\
\text { Signs }\end{array}$ & $\begin{array}{l}\text { Type } \\
\text { of } \\
\text { surgery }\end{array}$ & $\begin{array}{l}\text { Position } \\
\text { in } \\
\text { surgery }\end{array}$ & $\begin{array}{l}\text { Largest } \\
\text { cyst } \\
\text { diameter } \\
\text { in } \mathrm{mm}\end{array}$ & Complications & Outcome & $\operatorname{ccos}$ \\
\hline 21 & $16 \mathrm{~F}$ & $\begin{array}{l}\text { Headache, } \\
\text { nausea, emesis, } \\
\text { malaise, sleep } \\
\text { disorder, } \\
\text { memory deficit }\end{array}$ & MTR & SS & 14 & $\begin{array}{l}\text { Air embolism, } \\
\text { blurred vision } \\
\text { after surgery }\end{array}$ & $\begin{array}{l}\text { Headache, } \\
\text { nausea, } \\
\text { vomiting } \\
\text { improved } \\
\text { markedly, } \\
\text { blurred vision } \\
\text { resolved, } \\
\text { sleep } \\
\text { disorder and } \\
\text { memory } \\
\text { deficit not } \\
\text { changed }\end{array}$ & 14 \\
\hline 22 & $24 \mathrm{M}$ & $\begin{array}{l}\text { Headache, } \\
\text { generalized } \\
\text { malaise }\end{array}$ & MTR & SS & 14 & - & $\begin{array}{l}\text { No } \\
\text { complaints }\end{array}$ & 16 \\
\hline 23 & $29 \mathrm{~F}$ & $\begin{array}{l}\text { Headache, } \\
\text { dizziness, } \\
\text { nausea, blurred } \\
\text { vision, facial } \\
\text { hemihypothesia }\end{array}$ & MTR & SS & 10 & $\begin{array}{l}\text { Headache, } \\
\text { nausea and } \\
\text { blurred vision } \\
\text { worsened after } \\
\text { surgery }\end{array}$ & $\begin{array}{l}\text { No } \\
\text { improvement }\end{array}$ & 8 \\
\hline 24 & $46 \mathrm{~F}$ & $\begin{array}{l}\text { Headache, } \\
\text { dizziness, } \\
\text { nausea, blurred } \\
\text { vision, malaise, } \\
\text { sleep disorder }\end{array}$ & MTR & $\mathrm{CC}$ & 18 & - & $\begin{array}{l}\text { No } \\
\text { complaints }\end{array}$ & 16 \\
\hline 25 & $23 \mathrm{~F}$ & $\begin{array}{l}\text { Headache, } \\
\text { nausea, } \\
\text { diplopia, blurred } \\
\text { vision, upward } \\
\text { gaze paresis, } \\
\text { tinnitus, } \\
\text { dysphagia }\end{array}$ & MTR & SS & 21 & $\begin{array}{l}\text { Air embolism, } \\
\text { blurred vision } \\
\text { worsened after } \\
\text { surgery }\end{array}$ & $\begin{array}{l}\text { Headache, } \\
\text { nausea, } \\
\text { diplopia, } \\
\text { upward gaze } \\
\text { paresis } \\
\text { resolved } \\
\text { completely, } \\
\text { blurred vision } \\
\text { improved, } \\
\text { tinnitus, } \\
\text { dysphagia } \\
\text { remained } \\
\text { unchanged }\end{array}$ & 14 \\
\hline 26 & $15 \mathrm{M}$ & $\begin{array}{l}\text { Headache, } \\
\text { nausea, emesis, } \\
\text { ataxia, sleeping } \\
\text { disorder }\end{array}$ & MTR & SS & 9 & $\begin{array}{l}\text { Occipital } \\
\text { wound healing } \\
\text { defect }\end{array}$ & $\begin{array}{l}\text { No } \\
\text { complaints }\end{array}$ & 16 \\
\hline 27 & $38 \mathrm{~F}$ & $\begin{array}{l}\text { Headache, } \\
\text { sleeping } \\
\text { disorder }\end{array}$ & MTR & SS & 10 & CSF fistula & $\begin{array}{l}\text { No } \\
\text { complaints }\end{array}$ & 16 \\
\hline 28 & $31 \mathrm{M}$ & $\begin{array}{l}\text { Headache, } \\
\text { nausea, } \\
\text { diplopia, } \\
\text { memory deficit, } \\
\text { sleeping } \\
\text { disorder }\end{array}$ & MTR & SS & 15 & - & $\begin{array}{l}\text { No } \\
\text { complaints }\end{array}$ & 16 \\
\hline
\end{tabular}

Abbreviations:

MTR: microsurgical total resection, MSR: microsurgical subtotal resection, SS: semi-sitting, CC: Concord, CCOS: Chicago Chiari Outcome Score 


\begin{tabular}{|c|c|c|c|c|c|c|c|c|}
\hline $\begin{array}{l}\text { Absolute } \\
\text { Nr. }\end{array}$ & $\begin{array}{l}\text { Age at } \\
\text { surgery } \\
\text { /Gender }\end{array}$ & $\begin{array}{l}\text { Symptoms / } \\
\text { Signs }\end{array}$ & $\begin{array}{l}\text { Type } \\
\text { of } \\
\text { surgery }\end{array}$ & $\begin{array}{l}\text { Position } \\
\text { in } \\
\text { surgery }\end{array}$ & $\begin{array}{l}\text { Largest } \\
\text { cyst } \\
\text { diameter } \\
\text { in } \mathrm{mm}\end{array}$ & Complications & Outcome & $\operatorname{ccos}$ \\
\hline 29 & $23 \mathrm{~F}$ & $\begin{array}{l}\text { Headache, } \\
\text { nausea }\end{array}$ & MTR & SS & 9 & - & $\begin{array}{l}\text { No } \\
\text { complaints }\end{array}$ & 16 \\
\hline 30 & $52 \mathrm{~F}$ & $\begin{array}{l}\text { Headache, } \\
\text { nausea }\end{array}$ & MTR & SS & 17 & - & $\begin{array}{l}\text { No } \\
\text { complaints }\end{array}$ & 16 \\
\hline 31 & $33 \mathrm{~F}$ & $\begin{array}{l}\text { Headache, } \\
\text { nausea, } \\
\text { malaise, } \\
\text { sleeping } \\
\text { disorder }\end{array}$ & MTR & SS & 13 & $\begin{array}{l}\text { Small air } \\
\text { embolism }\end{array}$ & $\begin{array}{l}\text { Headache } \\
\text { improved } \\
\text { markedly, no } \\
\text { other } \\
\text { symptoms }\end{array}$ & 15 \\
\hline 32 & $12 \mathrm{~F}$ & $\begin{array}{l}\text { Headache, } \\
\text { dizziness, } \\
\text { ataxia, malaise, } \\
\text { sleeping } \\
\text { disorder }\end{array}$ & MTR & SS & 17 & CSF fistula & $\begin{array}{l}\text { No } \\
\text { complaints }\end{array}$ & 16 \\
\hline 33 & $21 \mathrm{~F}$ & $\begin{array}{l}\text { Headache, } \\
\text { nausea, blurred } \\
\text { vision, } \\
\text { concentration } \\
\text { deficit }\end{array}$ & MSR & SS & 26 & - & $\begin{array}{l}\text { No } \\
\text { complaints }\end{array}$ & 16 \\
\hline 34 & $16 \mathrm{~F}$ & $\begin{array}{l}\text { Headache, } \\
\text { nausea }\end{array}$ & MTR & SS & 21 & Pneuomothorax & $\begin{array}{l}\text { No } \\
\text { complaints }\end{array}$ & 16 \\
\hline 35 & $36 \mathrm{~F}$ & $\begin{array}{l}\text { Headache, } \\
\text { nausea, } \\
\text { dizziness, } \\
\text { generalized } \\
\text { hypothesia }\end{array}$ & MTR & SS & 16 & - & $\begin{array}{l}\text { No } \\
\text { improvement }\end{array}$ & 10 \\
\hline 36 & $28 \mathrm{M}$ & $\begin{array}{l}\text { Headache, } \\
\text { nausea, } \\
\text { diplopia } \\
\text { sleeping } \\
\text { disorder, } \\
\text { dizzines }\end{array}$ & MTR & SS & 22 & $\begin{array}{l}\text { Transient } \\
\text { numbness left } \\
\text { leg }\end{array}$ & $\begin{array}{l}\text { Marked } \\
\text { improvement }\end{array}$ & 14 \\
\hline 37 & $42 \mathrm{~F}$ & $\begin{array}{l}\text { Headache, } \\
\text { nausea, } \\
\text { sleeping } \\
\text { disorder, blurred } \\
\text { vision, } \\
\text { dizziness }\end{array}$ & MTR & SS & 19 & - & $\begin{array}{l}\text { No } \\
\text { compliants }\end{array}$ & 16 \\
\hline 38 & $36 \mathrm{M}$ & $\begin{array}{l}\text { Headache, } \\
\text { nausea, emesis, } \\
\text { dizziness, } \\
\text { blurred vision, } \\
\text { diplopia, } \\
\text { concentration } \\
\text { deficit, sleeping } \\
\text { disorder }\end{array}$ & MTR & SS & 20 & $\begin{array}{l}\text { Small air } \\
\text { embolism }\end{array}$ & $\begin{array}{l}\text { Marked } \\
\text { improvement }\end{array}$ & 14 \\
\hline
\end{tabular}

Abbreviations:

MTR: microsurgical total resection, MSR: microsurgical subtotal resection, SS: semi-sitting, CC: Concord, CCOS: Chicago Chiari Outcome Score 


\begin{tabular}{|c|c|c|c|c|c|c|c|c|}
\hline $\begin{array}{l}\text { Absolute } \\
\text { Nr. }\end{array}$ & $\begin{array}{l}\text { Age at } \\
\text { surgery } \\
\text { /Gender }\end{array}$ & $\begin{array}{l}\text { Symptoms / } \\
\text { Signs }\end{array}$ & $\begin{array}{l}\text { Type } \\
\text { of } \\
\text { surgery }\end{array}$ & $\begin{array}{l}\text { Position } \\
\text { in } \\
\text { surgery }\end{array}$ & $\begin{array}{l}\text { Largest } \\
\text { cyst } \\
\text { diameter } \\
\text { in } \mathrm{mm}\end{array}$ & Complications & Outcome & $\operatorname{ccos}$ \\
\hline 39 & $29 \mathrm{~F}$ & $\begin{array}{l}\text { Headache, } \\
\text { nausea, } \\
\text { dizziness, } \\
\text { sleeping } \\
\text { disorder }\end{array}$ & MTR & SS & 27 & $\begin{array}{l}\text { Transient } \\
\text { tinnitus }\end{array}$ & $\begin{array}{l}\text { No } \\
\text { complaints }\end{array}$ & 16 \\
\hline 40 & $28 \mathrm{~F}$ & Headache & MTR & SS & 12 & $\begin{array}{l}\text { Impairment of } \\
\text { field of vision }\end{array}$ & $\begin{array}{l}\text { Unchanged } \\
\text { headache, } \\
\text { dizziness }\end{array}$ & 10 \\
\hline 41 & $26 \mathrm{~F}$ & $\begin{array}{l}\text { Headache, } \\
\text { dizziness, } \\
\text { malaise }\end{array}$ & MTR & SS & 13 & $\begin{array}{l}\text { Small air } \\
\text { embolism, } \\
\text { nystagmus }\end{array}$ & $\begin{array}{l}\text { Marked } \\
\text { improvement }\end{array}$ & 14 \\
\hline 42 & $35 \mathrm{~F}$ & $\begin{array}{l}\text { Headache, } \\
\text { nausea, vertigo, } \\
\text { sleeping } \\
\text { disorder, vision } \\
\text { problem }\end{array}$ & MTR & SS & 15 & $\begin{array}{l}\text { Transient } \\
\text { diplopia }\end{array}$ & $\begin{array}{l}\text { Marked } \\
\text { improvement }\end{array}$ & 14 \\
\hline 43 & $23 \mathrm{~F}$ & $\begin{array}{l}\text { Headache, } \\
\text { nausea }\end{array}$ & MTR & SS & 16 & - & $\begin{array}{l}\text { No } \\
\text { complaints }\end{array}$ & 15 \\
\hline 44 & $24 \mathrm{~F}$ & $\begin{array}{l}\text { Headache, } \\
\text { nausea, vertigo }\end{array}$ & MTR & SS & 12 & - & $\begin{array}{l}\text { No } \\
\text { complaints }\end{array}$ & 16 \\
\hline 45 & $31 \mathrm{~F}$ & Headache & MTR & SS & 20 & $\begin{array}{l}\text { Transient } \\
\text { numbness left } \\
\text { foot }\end{array}$ & $\begin{array}{l}\text { Marked } \\
\text { improvement }\end{array}$ & 14 \\
\hline 46 & $44 \mathrm{~F}$ & $\begin{array}{l}\text { Headache, } \\
\text { vision problem, } \\
\text { nausea, vertigo }\end{array}$ & MTR & $\mathrm{CC}$ & 16 & $\begin{array}{l}\text { Mild sleeping } \\
\text { disorder } \\
\text { (transient } \\
\text { Melatonin) }\end{array}$ & $\begin{array}{l}\text { Marked } \\
\text { improvement }\end{array}$ & 14 \\
\hline 47 & $34 \mathrm{~F}$ & $\begin{array}{l}\text { Headache, } \\
\text { nausea, } \\
\text { sleeping } \\
\text { disorder }\end{array}$ & MTR & $\mathrm{CC}$ & 15 & - & $\begin{array}{l}\text { Headache } \\
\text { improved, but } \\
\text { still memory } \\
\text { problems }\end{array}$ & 12 \\
\hline 48 & $56 \mathrm{~F}$ & $\begin{array}{l}\text { Headache, } \\
\text { diplopia, blurred } \\
\text { vision, vertigo }\end{array}$ & MTR & $\mathrm{CC}$ & 13 & - & $\begin{array}{l}\text { Improved } \\
\text { headache, } \\
\text { still wound } \\
\text { pain }\end{array}$ & 11 \\
\hline 49 & $51 \mathrm{M}$ & $\begin{array}{l}\text { Headache, } \\
\text { nausea, } \\
\text { syncope, } \\
\text { vertigo }\end{array}$ & MSR & SS & 21 & $\begin{array}{l}\text { Small air } \\
\text { embolism, } \\
\text { transient } \\
\text { paresis in foot } \\
\text { (media } \\
\text { infarction) }\end{array}$ & $\begin{array}{l}\text { No } \\
\text { complaints }\end{array}$ & 16 \\
\hline 50 & $46 \mathrm{M}$ & $\begin{array}{l}\text { Headache, } \\
\text { nausea }\end{array}$ & MTR & SS & 9 & $\begin{array}{l}\text { Sleeping } \\
\text { disorder }\end{array}$ & $\begin{array}{l}\text { No } \\
\text { improvement }\end{array}$ & 11 \\
\hline 51 & $29 \mathrm{~F}$ & $\begin{array}{l}\text { Headache, } \\
\text { diplopia, } \\
\text { vertigo, nausea }\end{array}$ & MTR & SS & 7 & - & $\begin{array}{l}\text { No } \\
\text { complaints }\end{array}$ & 16 \\
\hline
\end{tabular}

Abbreviations:

MTR: microsurgical total resection, MSR: microsurgical subtotal resection, SS: semi-sitting, CC: Concord, CCOS: Chicago Chiari Outcome Score 


\begin{tabular}{|c|c|c|c|c|c|c|c|c|}
\hline $\begin{array}{l}\text { Absolute } \\
\text { Nr. }\end{array}$ & $\begin{array}{l}\text { Age at } \\
\text { surgery } \\
\text { /Gender }\end{array}$ & $\begin{array}{l}\text { Symptoms / } \\
\text { Signs }\end{array}$ & $\begin{array}{l}\text { Type } \\
\text { of } \\
\text { surgery }\end{array}$ & $\begin{array}{l}\text { Position } \\
\text { in } \\
\text { surgery }\end{array}$ & $\begin{array}{l}\text { Largest } \\
\text { cyst } \\
\text { diameter } \\
\text { in } \mathrm{mm}\end{array}$ & Complications & Outcome & ccos \\
\hline 52 & $26 \mathrm{~F}$ & $\begin{array}{l}\text { Headache, } \\
\text { blurred vision, } \\
\text { nausea }\end{array}$ & MTR & $\mathrm{CC}$ & 9 & $\begin{array}{l}\text { Diplopia, } \\
\text { occipital } \\
\text { numbness }\end{array}$ & $\begin{array}{l}\text { Still occipital } \\
\text { numbness, } \\
\text { only } \\
\text { headache } \\
\text { improved }\end{array}$ & 10 \\
\hline 53 & $12 \mathrm{~F}$ & $\begin{array}{l}\text { Headache, } \\
\text { nausea, } \\
\text { diplopia }\end{array}$ & MTR & SS & 22 & - & $\begin{array}{l}\text { Still } \\
\text { headaches, } \\
\text { nausea, } \\
\text { concentration } \\
\text { deficit }\end{array}$ & 9 \\
\hline 54 & $28 \mathrm{~F}$ & $\begin{array}{l}\text { Headache, } \\
\text { nausea, vision } \\
\text { problems }\end{array}$ & MTR & SS & 13 & - & $\begin{array}{l}\text { Still } \\
\text { headaches, } \\
\text { manageable } \\
\text { with } \\
\text { medication }\end{array}$ & 12 \\
\hline 55 & $13 \mathrm{~F}$ & $\begin{array}{l}\text { Headache, } \\
\text { vertigo, nausea }\end{array}$ & MTR & SS & 13 & - & $\begin{array}{l}\text { Marked } \\
\text { improvement }\end{array}$ & 15 \\
\hline 56 & $14 \mathrm{~F}$ & $\begin{array}{l}\text { Headache, } \\
\text { concentration } \\
\text { disorder }\end{array}$ & MTR & SS & 16 & - & $\begin{array}{l}\text { Headache } \\
\text { improved, } \\
\text { concentration } \\
\text { disturbance }\end{array}$ & 13 \\
\hline 57 & $17 \mathrm{~F}$ & $\begin{array}{l}\text { Headache, } \\
\text { sleeping } \\
\text { disorder }\end{array}$ & MTR & SS & 14 & - & $\begin{array}{l}\text { Marked } \\
\text { improvement }\end{array}$ & 13 \\
\hline 58 & $41 \mathrm{M}$ & Headache & MTR & SS & 17 & $\begin{array}{l}\text { Small air } \\
\text { embolism }\end{array}$ & $\begin{array}{l}\text { Marked } \\
\text { improvement }\end{array}$ & 15 \\
\hline 59 & $28 \mathrm{M}$ & $\begin{array}{l}\text { Headache, } \\
\text { dizziness, } \\
\text { vertigo, vision } \\
\text { problems, } \\
\text { sleeping } \\
\text { disorder }\end{array}$ & MTR & SS & 12 & - & $\begin{array}{l}\text { Improved } \\
\text { headache }\end{array}$ & 14 \\
\hline 60 & $59 \mathrm{~F}$ & $\begin{array}{l}\text { Headache, } \\
\text { nausea, } \\
\text { dizziness }\end{array}$ & MTR & SS & 15 & - & & 13 \\
\hline 61 & $30 \mathrm{~F}$ & $\begin{array}{l}\text { Headache, } \\
\text { dizziness, } \\
\text { vision } \\
\text { problems, } \\
\text { sleeping } \\
\text { disorder }\end{array}$ & MTR & $\mathrm{CC}$ & 7 & - & $\begin{array}{l}\text { No } \\
\text { compliants }\end{array}$ & 16 \\
\hline 62 & $42 \mathrm{~F}$ & $\begin{array}{l}\text { Headache, } \\
\text { attack of } \\
\text { sweating }\end{array}$ & MTR & SS & 12 & - & & 15 \\
\hline \multicolumn{9}{|c|}{ Abbreviations: } \\
\hline
\end{tabular}

Importantly, the difficulty in attributing (all) their symptoms to the pineal cyst, and that their symptoms or at least part of them may have resulted from a temporary elevation in intracranial pressure was extensively discussed with the patients. Especially, that they may not benefit from surgery, and on the contrary, being exposed to the risks of surgery. 


\section{Surgery}

Preoperatively, transesophageal echocardiography was performed to rule out an open foramen ovale and to minimize the risks from air embolism. The surgical notes were reviewed regarding the approach, characteristics of cyst removal, and perioperative complications as mentioned above.

\section{Postoperative evaluation}

All patients from 2016 to 2020 were assessed prospectively after surgery and before discharge, 3 and 6 months after surgery and then yearly. All patients were followed finally until April 2021. The examinations were carried out by a neurosurgeon who was not directly involved in the surgery. The Chicago Chiari Outcome Scale ${ }^{4}$ (CCOS, see Table 2 ) was calculated.

Table 2

the Chicago Chiari Outcome Scale (CCOS) ${ }^{4}$ : a total score of 4-16; a final score of 4: incapacitated; 8: impaired outcome; 12 : functional outcome; 16: excellent outcome.

\begin{tabular}{|c|c|c|c|c|}
\hline \multicolumn{5}{|c|}{ Chicago Chiari Outcome Scale } \\
\hline Pain & Non-pain & Functionality & Complications & Total Score \\
\hline 1: Worse & 1: Worse & $\begin{array}{l}\text { 1: Unable to } \\
\text { attend }\end{array}$ & $\begin{array}{l}\text { 1: Persistent complication, } \\
\text { poorly controlled }\end{array}$ & $\begin{array}{l}\text { 4: Incapacitated } \\
\text { outcome }\end{array}$ \\
\hline $\begin{array}{l}\text { 2: Unchanged and } \\
\text { refractory } \\
\text { to medication }\end{array}$ & $\begin{array}{l}\text { 2: Unchanged or } \\
\text { improved } \\
\text { but impaired }\end{array}$ & $\begin{array}{l}\text { 2: Moderate } \\
\text { impairment } \\
\text { (<50\% } \\
\text { attendance) }\end{array}$ & $\begin{array}{l}\text { 2: Persistent complication, } \\
\text { well controlled }\end{array}$ & $\begin{array}{l}\text { 8: Impaired } \\
\text { outcome }\end{array}$ \\
\hline $\begin{array}{l}\text { 3: Improved or } \\
\text { controlled with } \\
\text { medication }\end{array}$ & $\begin{array}{l}\text { 3: Improved but } \\
\text { unimpaired }\end{array}$ & $\begin{array}{l}\text { 3: Mild } \\
\text { impairment (> } \\
50 \% \\
\text { of attendance) }\end{array}$ & 3: Transient complication & $\begin{array}{l}\text { 12: Functional } \\
\text { outcome }\end{array}$ \\
\hline 4: Resolved & 4: Resolved & 4: Fully functional & 4: Uncomplicated course & $\begin{array}{l}\text { 16: Excellent } \\
\text { outcome }\end{array}$ \\
\hline
\end{tabular}

Májovsky et al. used this score to assess the clinical outcome of patients with symptomatic pineal cysts as they have some similarities with patients with Chiari malformation ${ }^{25}$.

\section{Radiological evaluation}

The diameter of the pineal cyst was measured as maximum width of the cyst in a mid-sagittal T2-weighed or constructive interference in steady state (CISS) MR image.

\section{Surgical details}

Approach and Positioning

A microsurgical total cyst resection was performed via a supracerebellar-infratentorial approach (SCIT). Initially, we used the standard midline approach $(n=15)$. However, since 2015 we have used the less invasive small unilateral paramedian approach. This approach has the advantage that the viewing trajectory to the pineal region is not as steep as in the midline approach (see Fig. 4). Therefore, the surgeon's position is more convenient.

If a semi-sitting positioning is to be performed, it is necessary to exclude a persistent foramen ovale prior to surgery with the aid of transesophageal echocardiography. An open foramen ovale has the risk of direct air embolism into brain arteries. Therefore, it should be avoided and surgery was done in prone position $(n=9)$. 
Clearly, adequate cushioning of the patient is needed. Lower extremities should not be stretched-a cushion beneath the knees and comfortable positioning of the bottom with direct contact to the angled table is important. Compression socks with changing inflation reduces the risk of thrombosis.

The head is fixed sharply with a three-pin clamp and should be anteflexed, but not closer than $3 \mathrm{~cm}$ between chin and sternal manubrium to avoid jugular venous congestion. Furthermore, the anesthesiologists should have non-limited access to the jugular veins for intraoperative compression tests (Fig. 2: semi-sitting position).

Specific anesthesiological considerations

Specific anesthesiological preparations include central venous line with positioning of the tip in the atrium to aspirate air in case of embolism intraoperatively. Furthermore, infusion before starting the surgery to elevate the central venous pressure may help to reduce the risk of air embolism. During the operation, a permanent transesophageal echocardiographic monitoring offers the direct control of an ongoing air embolism.

Managing air embolism

Typical signs and symptoms of intraoperative air embolism are acute blood pressure depression, tachycardia, lowering of $\mathrm{O}_{2}$ saturation and decreased endexspiratory $\mathrm{CO}_{2}$ level.

Important intraoperative steps to manage are:

- jugular vein compression or PEEP (positive endexspiratory pressure) ventilation usually stops the air embolism immediately and is the most important maneuver to deal with air embolism. Additionally, it helps in finding the leakage point.

- lowering head-heart level with en-bloc movement of the operation table

- aspiration of air via central line

- irrigation of the operation field with saline and stepwise search for origin of air insufflation

An exact preparation of the operation field to prevent any air embolism includes:

- repeated control of any opening of venous system via jugular compression test (20-30 sec.) or PEEP

- use of bone wax to occlude emissarian veins

- adequate covering of bony edges and dura with gelfoam/tabotamp and soaked cottonoids.

Preoperative planning and radiographic landmarks

We use anatomical landmarks to perform the approach. Navigation was not applied.

We look carefully for any side predominance and height of the transverse sinus as well as the location of bridging veins. In children, we look additionally for an open occipital sinus. If one transverse sinus is high rising at the coronal MR image, we approach from that side because the angle of view is not so steep.

MR imaging with contrast-enhanced T1-weighted and T2-weighted images in axial and coronal plane shows the sinus and veins very well (see Fig. 3). The steepness of the tent is very variable (see Fig. 4).

We prefer a paramedian 2-cm wide supracerebellar approach on the non-dominant side of a high-rising transverse sinus, ideally with smaller or absent bridging veins.

Skin incision, bone flap

Page $11 / 25$ 
A straight 5-6 cm long skin incision beginning $1.5 \mathrm{~cm}$ over the level of the external occipital protuberance $2 \mathrm{~cm}$ paramedian to the midline is made. The fascia is incised and with careful sharp and blunt dissection we look for the major occipital nerve (Fig. 5a). Any injury of this nerve should be avoided because it may lead to severe neuropathic occipital pain and paresthesia. The semispinalis capitis and posterior rectus capitis muscles are incised and subperiosteally elevated. A selfretaining retractor is used to hold the incision open. A burrhole is placed exactly on the transverse sinus (Fig. 5b). Then, a 2$3 \mathrm{~cm}$ paramedian bone flap exposing the lower third of the transverse sinus is raised. After the craniotomy a jugular compression test is performed to make sure that no venous leak exists.

Opening of the dura, CSF drainage and bridging veins

The dura is incised $3 \mathrm{~mm}$ below and parallel to the transverse sinus (Fig. 5c). If there is a large patent occipital sinus (esp. in children) it is step by step incised and closed with stitches or alternatively with hemoclips clips (e. g. Hemoclip ${ }^{\circledR}$, Aesculap). Dural tacking stitches are placed to elevated the upper dural edge. This allows a view along the tent without any active retraction because of cerebellar retraction by gravity. Spatulas are not required. Careful covering of bone and dural edges after meticulous hemostasis is mandatory as mentioned above. Generally, it is very difficult and sometimes even impossible to predict the consequences of sacrificing of bridging veins. Cutting of bridging veins may lead to cerebellar congestion and swelling. Especially, if the veins have a larger diameter $(>2 \mathrm{~mm}$ ), vein sacrifice should be avoided. If somehow possible - we avoid occluding even smaller veins. If a larger vein is within the approach trajectory to the pineal gland, we dissect the vein from the cerebellar surface to allow a little bit of cerebellar retraction by gravity to enable access to the pineal cyst while avoiding vein sacrifice (Fig. 5d, e, f).

The arachnoid covering the pineal region is always thick. Before arachnoid incision, the large veins such as vein of Galen and Rosenthal needs to be identified. If they are collapsed, jugular compression should be performed. After opening of the quadrigeminal cistern CSF is drained. Surgeon`s patience while draining enough CSF is a key step for a gentle operation.

Dissection of the cyst

Injuries to the deep venous system are life - threatening and have to be avoided.

The internal cerebral and basal veins and many of their tributaries converge at the great cerebral vein (of Galen) in the posterior incisural space. The vein of the cerebellomesencephalic fissure crosses the quadrigeminal cistern (ambient cistern) and drains directly or via superior vermian vein to the vein of Galen. Arterial tributaries are defined as P3 segment of PCA (posterior cerebral artery) and also enter the quadrigeminal cistern ${ }^{23}$. After opening of the quadrigeminal cistern (ambient cistern), the cyst is exposed by meticulous sharp dissection (Fig. 5g). Always, a good arachnoid dissection plane can be found around the cyst. The cyst is incised and collapsed. Typically, the cysts contain a yellowish fluid. The cyst wall is grasped with a small tumor forceps and the arachnoid plane is dissected with an anatomical forceps (traction-counter traction technique ${ }^{29}$. Small feeding and draining vessels are coagulated and cut. The cyst is dissected from superior and inferior colliculi (quadrigeminal plate) beneath, from the thalamus laterally and from habenula and posterior commissure anteriorly. After cyst removal (Fig. 5h), a jugular compression test is done to detect potential venous bleeding sources.

Endoscopic visualization (Fig. 5i-k) incl. $30^{\circ}$ and $45^{\circ}$ optics is of help to look to surrounding structures. However, in view of the usually narrow surgical corridor and the intended preservation of bridging veins, we do not use a purely endoscopic technique since the risk of damaging the veins is much higher because they are not in the visual field of the endoscope.

\section{Closure}

The dura is closed with a running suture (Fig. 5n). Usually, we add sealants (e. g. Hemopatch ${ }^{\circledR}$, Baxter; Tachosil ${ }^{\circledR}$, Takeda) to prevent any cerebrospinal fluid (CSF) leak via the small stitch channels. Rarely, we use a small muscle patch in larger dural defects. Interestingly, despite the opening of the third ventricle, we rarely observed (see Table 3) CSF leaks after surgery. The bone flap is fixed with titanium miniplates (Fig. 50). The incision is closed in layers.

Page 12/25 
Table 3

detailed complications

\begin{tabular}{|c|c|c|}
\hline complication & $\mathrm{n}$ & therapy $(\mathrm{n}) /$ remarks \\
\hline pneumothorax & 2 & thoracal drainage (1) \\
\hline air embolism (intraoperative) & 8 & $\begin{array}{l}\text { relevant with circulatory impairment }(2) \text {; } \\
\text { venous aspiration }\end{array}$ \\
\hline pneumocephalus & $\begin{array}{l}\text { nearly } \\
\text { all }\end{array}$ & spontaneous resolution \\
\hline hydrocephalus & 0 & \\
\hline $\begin{array}{l}\text { discrete circumscribed abnormalities on diffusion MRI } \\
\text { postop) } \\
\text { discrete media infarction } \\
\text { (due to slight air embolism??) }\end{array}$ & $\begin{array}{l}5 \\
1\end{array}$ & $\begin{array}{l}\text { cerebellar (5) } \\
\text { without clinical sequelae } \\
\text { (transient) slight foot paresis }\end{array}$ \\
\hline rebleeding & 0 & \\
\hline meningitis & 0 & \\
\hline local wound infection & 1 & antibiotics \\
\hline CSF fistula & 2 & $\begin{array}{l}\text { subcutaneous effusion; } \\
\text { spontaneous resolution }\end{array}$ \\
\hline occipital hypesthesia & 1 & only numbness \\
\hline diplopia/ visual disturbancies & 11 & spontaneous resolution \\
\hline new mnestic deficits & 2 & \\
\hline ataxia & 0 & \\
\hline increased sleep disturbance & 2 & improved with melatonine \\
\hline tinnitus & 1 & spontaneous resolution \\
\hline peripheral nerve & 3 & $\begin{array}{l}\text { numbness (occipital nerve) (2), weakness (sciatic } \\
\text { nerve) (1) } \\
\text { spontaneous resolution }\end{array}$ \\
\hline
\end{tabular}

\section{Results}

Patients and presenting symptoms

Around 500 patients with pineal cysts were referred to our institution for evaluation from 2003 to 2020.73 patients underwent surgery for a pineal cyst. An absence of enlarged ventricles was documented in 62 patients (51 female, 11 male, mean age 27.67 yrs ( \pm 11.98 yrs), range $4-59$ yrs).

Presenting symptoms included headache (61/62), visual disturbances (23/62), dizziness/vertigo (24/62), nausea/emesis (41/62), sleep disturbances (17/62).

\section{Radiological findings}


Preoperative mid-sagittal MRI (CISS or T2-weighted) usually demonstrated narrowing but no occlusion of the aqueduct due to the pineal cyst (Fig. 1). The cyst size ranged from 7 to $27 \mathrm{~mm}$ (mean $15.17 \mathrm{~mm}$ ) in maximal diameter. Enlarged ventricles were not observed. There was radiological evidence of cyst enlargement in preoperative follow-up MRI series in 6 of 62 patients. MRI obtained one day after surgery demonstrated no cyst remnant in all patients. Furthermore, there was no cyst recurrence during the follow up period (mean 26.6 months (range: 6-139 months)).

\section{Clinical Outcome}

55 of $62(89 \%)$ patients improved after surgery with good or even excellent results according to the Chicago Chiari Outcome Scale (CCOS $\geq 12$ ), with complete or partial resolution of the leading symptoms within a mean follow-up period of 26.6 months (range: 6-139 month). Details of outcome are shown in Table 1.

The average hospital stay was 7 days (days ( \pm 3.5 days, range $5-22$ days). The longer hospital stays were due to completion of the preoperative investigations. All patients were discharged to their homes. Neither direct referrals to rehabilitation centers nor long-term care facilities were needed.

\section{Surgery}

The semi-sitting position was used in 53 patients. Otherwise, we operated them in prone position in case of persistent oval foramen $(n=9)$.

In all patients, a microsurgical cyst resection was performed via a supracerebellar-infratentorial approach (SCIT). Total cyst resection could be achieved in 59 of 62 patients. Initially, we used the standard midline approach $(n=15)$. However, since 2015 we have used the less invasive small unilateral paramedian approach $(n=47)$.

The operation time was in average 211 (+/-51) min (range 108 to $346 \mathrm{~min}$ ).

Peri- and postoperative complications

Air embolism occurred in 8 patients. In only 2 of these patients, we encountered a significant air embolism with circulatory impairment during surgery which was managed with jugular vein compression to visualize the venous leak, and aspiration of air from the heart via the central line. In the other 6 patients, air embolism was only detected by the cardiac ultrasound. In all patients, air embolism had no sequelae. Intraoperative major surgical complications were not observed.

Pathology approved all resected cysts as simple pineal cysts without evidence of malignancy.

11 patients suffered from transient visual problems after surgery (diplopia in 5 patients, blurring of vision in 4 patients, nystagmus ( $n=1)$ and 1 visual field defect). However, a detailed neuroophthalmological examination after surgery did not demonstrate any deficit in these patients. These symptoms resolved completely within 2-4 weeks after surgery in all patients.

One patient suffered from a wound infection and was managed conservatively.

Only two subcutaneous CSF effusions occurred and resolved spontaneously. A postoperative hydrocephalus was not observed.

Further detailed information is shown in Table 3.

\section{Discussion}


To our knowledge, this series is the largest surgical series of patients who underwent resection of a simple pineal cyst without hydrocephalus. Most of our patients showed a good to excellent outcome which is in accordance with the literature.

Evaluating CCOS, in our series 55 of 62 (89\%) patients reported good outcome with more than 11 points. In all patients, ventriculomegaly was not present suggesting that the absence of ventriculomegaly and / or tectum induced visual disturbances (Parinaud's syndrome) is not a contraindications for surgery. Therefore, a surgical intervention should not be generally refused in case of an absent ventriculomegaly in patients with leading symptoms indicating a possible temporary increase of intracranial pressure.

Pineal cysts rarely cause symptoms ${ }^{1-3}$. They are usually assumed as incidental findings and were often identified during workup for headache. Mostly, they are not the cause of symptoms ${ }^{3,7,9,38}$. According to the literature, large pineal cysts are considered to be potentially symptomatic lesions ${ }^{21}$ while causing ventriculomegaly due to compression of the Sylvian aqueduct or Parinaud's syndrome due to tectal compression 8,16,17,21,24,31,33-35,47,49.

Therefore, the discussion about the best management of patients with a pineal cyst without clear signs and symptoms of intracranial hypertension or symptomatic mass effect is still ongoing. There are some case series describing surgical results in pineal cysts without hydrocephalus or tectal compression. Kalani et al. ${ }^{21}$ reported in 17 of 18 patients with resection of pineal cysts a resolution or improvement of their presenting symptoms. The authors suggest that the absence of ventriculomegaly and Parinaud's syndrome are not absolute contraindications to surgical intervention.

Our previous results (series of 43 patients operated on pineal cyst without enlarged ventricles) could already demonstrate good to excellent clinical results ${ }^{13}$. In this period (2003 to 2018) we examined and followed 440 patients with pineal region pathologies according to Diagnosis Related Groups (DRG) codes.

However, we should clearly state that most pineal cysts are asymptomatic and do not require treatment. It is illustrated by Al-Holou and coworkers ${ }^{3}$ who reviewed in one of the largest studies more than 48,000 adult patients undergoing brain MRI: They discovered 478 incidental pineal cysts greater than $5 \mathrm{~mm}$ on MRI. Headache was presented in $21 \%$ of them, but no cysts were considered as symptomatic, and surgical intervention was not indicated. During follow-up, $99 \%$ of cysts remained stable or even decreased in size.

Obviously, patients should be thoroughly investigated before deciding for a surgical resection in case of such a benign lesion, and in view of the potential risk in this approach. Nevertheless, we believe that our results indicate that surgery may be an option after careful selection of patients to offer the possibility of marked relief of their symptoms and better quality of life in a small subset of pineal cyst patients.

Similar results were presented by Eide and Ringstad ${ }^{12}$ who collected 27 patients managed surgically for non-hydrocephalic pineal cysts over a 10-year period.

The compression of the internal cerebral veins, vein of Rosenthal or vein of Galen may influence the severity of symptoms in subjects with pineal cysts ${ }^{11}$. The resulting central venous hypertension might cause mild edema within the territories drained by the affected veins. MRI biomarkers indicating central venous hypertension have recently been reported ${ }^{10}$.

Májovsky et al. reported over 110 patients with simple pineal cysts. The most common presenting symptoms were tension headache (62.7\%), vertigo (16.4\%), migraine (12.7\%), syncope (10.9\%), nausea (8.2\%), and diplopia (8.2\%). Twenty-one patients underwent pineal cyst resection; 20 patients (95.2\%) reported some improvement in their presenting symptoms, and 10 patients (47.6\%) were completely free after the surgery ${ }^{25}$. Their results of the surgical group are comparable to our results after surgery. We reported in $95 \%$ a good outcome after surgery and a very low incidence of complications ${ }^{13}$. Constantly, we can also demonstrate a low rate of complications with our recent cohort. 
Recently, Masina, and Santarius et al. published a meta-analysis of the published literature adressing the surgical treatment of symptomatic pineal cysts without hydrocephalus. They concluded that although the results support the role of surgery in the management of this entity, they have to be interpreted with a great deal of caution as the current evidence is limited, consisting only of case reports and retrospective surgical series. Inherent to such studies are inhomogeneity and incompleteness of data, selection bias and bias related to assessment of outcome carried out by the treating surgeon in the majority of cases. Prospective studies with patient-reported and objective outcome assessment are needed to provide higher level of evidence ${ }^{30}$.

Some aspects of the surgical approach have to be discussed:

The SCIT represents an extraparenchymatous approach via a natural corridor. Alternatives might be the occipital transtentorial approach (OTT) and the occipital bi-transtentorial/falcine approach ${ }^{23}$ or - only in case of enlarged ventricles the frontal endoscopic approach. We would not suggest the OTT because the pineal cyst is located under the tent and veins. Why should we come from above with the need to cut the tent? Furthermore, there is a risk of postoperative hemianopia $5,39,50$. Also, pure endoscopic SCIT has been described ${ }^{19}$. However, the narrow surgical corridor in our minimally invasive paramedian approach, does not allow an unrestricted manual dissection with an endoscope.

We prefer the (semi-) sitting position (Fig. 2): Advances are proper gravity-induced cerebellar retraction and fluid drainage which avoids a limited view in the depth and the need for suction. Otherwise, the prone position offers a safe alternative in view of the risk of air embolism.

To leave small amounts of pineal tissue behind in view of preservation of melatonin production has been suggested previously ${ }^{25}$, but we usually perform a total cyst removal. We have only seen a few temporary sleep problems which were treated with a temporary melatonin substitution. Furthermore, it is not proven that a small piece of cyst will work physiologically.

\section{Key Issues On Selection Of Patients:}

We assumed that the leading symptoms (headache, nausea, vomiting) of the patients are caused by a temporary increase of the intracranial pressure due to the partial aqueduct compression. During attacks of emesis, the intracranial pressure might be markedly elevated so that the compression of the aqueduct is overcome. All other potential causes for the complaints must be excluded. All patients had been thoroughly investigated prior to surgery in view of the leading symptoms (ophthalmology, neurology or neuropediatrics, internal medicine, neuropsychology, psychiatry) to rule out any other possible cause for their symptoms. We have to clearly state that the decision for resection of a simple pineal cyst without ventriculomegaly has to be taken with caution and after a long discussion with the patient and failure of all other conservative measures to control his or her symptoms.

\section{Limitation}

We could not rule out any placebo effect. It was pointed out that young female patients are more susceptible to placebo effect ${ }^{48}$. Most of our series were young females. However, the long-term success in most of our patients as well as the improvement in our pediatric cohort makes a placebo-effect very unlikely. Although, the patient cohort is still a subject to selection bias as most of the patients with pineal cysts and without symptoms do not seek medical attention. Furthermore, we have to state that our study is a case study (level of evidence 4 according to the Oxford Centre of Evidence-based Medicine).

\section{Conclusion}

Page $16 / 25$ 
To date, scientific information about surgical therapy of pineal cysts without hydrocephalus has been limited. We suggest that pineal cysts resection can be done also in the absence of ventriculomegaly in selected patients. The high percentage of postoperative resolution of quality of life limiting symptoms in our series demonstrates a good indication for pineal cyst resection. Preoperatively, other causes of the leading symptoms have to be excluded. Intermittent occlusion of the aqueduct may cause increased intracranial pressure leading to intermittent symptoms. Furthermore, a possible venous hypertension due to compression of the deep venous structures through the pineal cyst may also be responsible for the symptoms. However, the decision-making remains difficult since no reliable predictors are available. There is still insufficient scientific evidence to generally recommend this technique as a treatment for headache and other unspecific symptoms.

\section{Abbreviations}

$\begin{array}{ll}\text { CCOS } & \text { Chicago Chiari Outcome Scale } \\ \text { CISS } & \text { Constructive Interference in Steady State } \\ \text { CSF } & \text { cerebrospinal fluid } \\ \text { DRG } & \text { Diagnosis Related Groups } \\ \text { PEEP } & \text { positive endexspiratory pressure } \\ \text { SCIT } & \text { supracebellar infratentorial approach }\end{array}$

\section{Declarations}

\section{Publishing}

The manuscript has not been submitted to another journal for simultaneous consideration.

\section{Funding}

The authors declare that no funds, grants, or other support were received during the preparation of this manuscript.

\section{Competing Interests}

The authors have no relevant financial or non-financial interests to disclose.

\section{Ethics}

The study complied with the Declaration of Helsinki and was approved by the ethics committee of University Medicine Greifswald. All patients gave written informed consent.

\section{Data transparency}

There is availability of data and material on demand.

\section{Code availability}

Software application or custom code: not applicable.

\section{Author's contribution}


All authors meet all 3 of the following conditionsin accordance with the "Consensus Statement on Surgery Journals Authorship-2005":

1) Authors make substantial contributions to conception and design, and/or acquisition of data, and/or analysis and interpretation of data;

2) Authors participate in drafting the article or revising it critically for important intellectual content; and

3) Authors give final approval of the version to be submitted and any revised version.

\section{Consent for publication}

The authors transfer to Springer (respective to owner if other than Springer and for U.S. government employees: to the extent transferable) the non-exclusive publication rights and he warrants that his/her contribution is original and that he/she has full power to make this grant. The author signs for and accepts responsibility for releasing this material on behalf of any and all co-authors. This transfer of publication rights covers the non-exclusive right to reproduce and distribute the article, including reprints, translations, photographic reproductions, microform, electronic form (offline, online) or any other reproductions of similar nature.

The author may self-archive an author-created version of his article on his own website and his institution's repository, including his final version; however he may not use Springer's PDF version which is posted on www.springerlink.com. Furthermore, the author may only post his version provided acknowledgement is given to the Journal and Springer as one of the original places of publication and a link is inserted to the published article on Springer's website.

\section{References}

1. Al-Holou WN, Garton HJ, Muraszko KM, Ibrahim M, Maher CO (2009) Prevalence of pineal cysts in children and young adults. Clinical article. J Neurosurg Pediatr 4:230-236

2. Al-Holou WN, Maher CO, Muraszko KM, Garton HJ (2010) The natural history of pineal cysts in children and young adults. J Neurosurg Pediatr 5:162-166

3. Al-Holou WN, Terman SW, Kilburg C, Garton HJ, Muraszko KM, Chandler WF et al (2011) Prevalence and natural history of pineal cysts in adults. J Neurosurg 115:1106-1114

4. Aliaga L, Hekman KE, Yassari R, Straus D, Luther G, Chen J et al (2012) A novel scoring system for assessing Chiari malformation type I treatment outcomes. Neurosurgery 70:656-664 discussion $664-655$

5. Berhouma M, Ni H, Delabar V, Tahhan N, Memou Salem S, Mottolese C et al (2015) Update on the management of pineal cysts: Case series and a review of the literature. Neurochirurgie 61:201-207

6. Chandy MJ, Damaraju SC (1998) Benign tumours of the pineal region: a prospective study from 1983 to $1997 . \mathrm{Br} J$ Neurosurg 12:228-233

7. Choy W, Kim W, Spasic M, Voth B, Yew A, Yang I Pineal cyst: a review of clinical and radiological features. Neurosurg Clin N Am22:341-351, vii, 2011

8. Costa F, Fornari M, Valla P, Servello D (2008) Symptomatic pineal cyst: case report and review of the literature. Minim Invasive Neurosurg 51:231-233

9. Di Costanzo A, Tedeschi G, Di Salle F, Golia F, Morrone R, Bonavita V (1993) Pineal cysts: an incidental MRI finding? J Neurol Neurosurg Psychiatry 56:207-208

10. Eide PK, Pripp AH, Ringstad GA (2016) Magnetic resonance imaging biomarkers indicate a central venous hypertension syndrome in patients with symptomatic pineal cysts. J Neurol Sci 363:207-216

11. Eide PK, Ringstad G (2016) Increased pulsatile intracranial pressure in patients with symptomatic pineal cysts and magnetic resonance imaging biomarkers indicative of central venous hypertension. J Neurol Sci 367:247-255

Page $18 / 25$ 
12. Eide PK, Ringstad G (2017) Results of surgery in symptomatic non-hydrocephalic pineal cysts: role of magnetic resonance imaging biomarkers indicative of central venous hypertension. Acta Neurochir (Wien) 159:349-361

13. El Damaty A, Fleck S, Matthes M, Baldauf J, Schroeder HWS (2019) Pineal Cyst without Hydrocephalus: Clinical Presentation and Postoperative Clinical Course After Infratentorial Supracerebellar Resection. World Neurosurg 129:e530-e537

14. Engel U, Gottschalk S, Niehaus L, Lehmann R, May C, Vogel S et al (2000) Cystic lesions of the pineal region-MRI and pathology. Neuroradiology 42:399-402

15. Evans RW, Peres MF (2010) Headaches and pineal cysts. Headache 50:666-668

16. Fain JS, Tomlinson FH, Scheithauer BW, Parisi JE, Fletcher GP, Kelly PJ et al (1994) Symptomatic glial cysts of the pineal gland. J Neurosurg 80:454-460

17. Fetell MR, Bruce JN, Burke AM, Cross DT, Torres RA, Powers JM et al (1991) Non-neoplastic pineal cysts. Neurology 41:1034-1040

18. Golzarian J, Baleriaux D, Bank WO, Matos C, Flament-Durand J (1993) Pineal cyst: normal or pathological? Neuroradiology 35:251-253

19. Gore PA, Gonzalez LF, Rekate HL, Nakaji P Endoscopic supracerebellar infratentorial approach for pineal cyst resection: technical case report.Neurosurgery62:108-109; discussion 109, 2008

20. Hasegawa A, Ohtsubo K, Mori W (1987) Pineal gland in old age; quantitative and qualitative morphological study of 168 human autopsy cases. Brain Res 409:343-349

21. Kalani MY, Wilson DA, Koechlin NO, Abuhusain HJ, Dlouhy BJ, Gunawardena MP et al (2015) Pineal cyst resection in the absence of ventriculomegaly or Parinaud's syndrome: clinical outcomes and implications for patient selection. $J$ Neurosurg 123:352-356

22. Kang HS, Kim DG, Han DH (1998) Large glial cyst of the pineal gland: a possible growth mechanism. Case report. J Neurosurg 88:138-140

23. Kawashima M, Rhoton AL Jr, Matsushima T (2002) Comparison of posterior approaches to the posterior incisural space: microsurgical anatomy and proposal of a new method, the occipital bi-transtentorial/falcine approach. Neurosurgery 51:1208-1220 discussion 1220 - 1201

24. Klein P, Rubinstein LJ (1989) Benign symptomatic glial cysts of the pineal gland: a report of seven cases and review of the literature. J Neurol Neurosurg Psychiatry 52:991-995

25. Majovsky M, Netuka D, Benes V (2017) Conservative and Surgical Treatment of Patients with Pineal Cysts: Prospective Case Series of 110 Patients. World Neurosurg 105:199-205

26. Majovsky M, Netuka D, Benes V (2018) Is surgery for pineal cysts safe and effective? Short review. Neurosurg Rev 41:119-124

27. Mamourian AC, Towfighi J (1986) Pineal cysts: MR imaging. AJNR Am J Neuroradiol 7:1081-1086

28. Mandera M, Marcol W, Bierzynska-Macyszyn G, Kluczewska E (2003) Pineal cysts in childhood. Childs Nerv Syst 19:750-755

29. Marx S, El Refaee E, Langner S, Schroeder HWS (2017) Four-Hand Suction-Irrigation Technique Leads to Gross Total Resection and Long-Term Progression-Free Survival in Fourth Ventricular Ependymoma. World Neurosurg 107:437-444

30. Masina R, Ansaripour A, Benes V, Berhouma M, Choque-Velasquez J, Eide PK et al (2021) : Surgical treatment of symptomatic pineal cysts without hydrocephalus-meta-analysis of the published literature. Acta Neurochir (Wien),

31. Maurer PK, Ecklund J, Parisi JE, Ondra S Symptomatic pineal cyst: case report.Neurosurgery27:451-453; discussion $453-454,1990$

32. McNeely PD, Howes WJ, Mehta V (2003) Pineal apoplexy: is it a facilitator for the development of pineal cysts? Can J Neurol Sci 30:67-71 
33. Michielsen G, Benoit Y, Baert E, Meire F, Caemaert J Symptomatic pineal cysts: clinical manifestations and management.Acta Neurochir (Wien)144:233-242; discussion 242, 2002

34. Oeckler R, Feiden W (1991) Benign symptomatic lesions of the pineal gland. Report of seven cases treated surgically. Acta Neurochir (Wien) 108:40-44

35. Osborn RE, Deen HG, Kerber CW, Glass RF (1989) A case of hemorrhagic pineal cyst: MR/CT correlation. Neuroradiology 31:187-189

36. Patel AJ, Fuller GN, Wildrick DM, Sawaya R Pineal cyst apoplexy: case report and review of the literature.Neurosurgery57:E1066; discussion E1066, 2005

37. Pitskhelauri DI, Konovalov AN, Abramov IT, Danilov GV, Pronin IN, Alexandrova EV et al (2019) Pineal Cyst-Related Aqueductal Stenosis as Cause of Intractable Headaches in Nonhydrocephalic Patients. World Neurosurg 123:e147e155

38. Pu Y, Mahankali S, Hou J, Li J, Lancaster JL, Gao JH et al (2007) High prevalence of pineal cysts in healthy adults demonstrated by high-resolution, noncontrast brain MR imaging. AJNR Am J Neuroradiol 28:1706-1709

39. Qi S, Fan J, Zhang XA, Zhang H, Qiu B, Fang L (2014) Radical resection of nongerminomatous pineal region tumors via the occipital transtentorial approach based on arachnoidal consideration: experience on a series of 143 patients. Acta Neurochir (Wien) 156:2253-2262

40. Sawamura Y, Ikeda J, Ozawa M, Minoshima Y, Saito H, Abe H Magnetic resonance images reveal a high incidence of asymptomatic pineal cysts in young women.Neurosurgery37:11-15; discussion 15-16, 1995

41. Seifert CL, Woeller A, Valet M, Zimmer C, Berthele A, Tolle T et al (2008) Headaches and pineal cyst: a case-control study. Headache 48:448-452

42. Stern JD, Ross DA Stereotactic management of benign pineal region cysts: report of two cases.Neurosurgery32:310314; discussion 314, 1993

43. Tapp E, Huxley M (1972) The histological appearance of the human pineal gland from puberty to old age. J Pathol 108:137-144

44. Tartara F, Regolo P, Terreni MR, Giovanelli M (2000) Glial cyst of the pineal gland: case report and considerations about surgical management. J Neurosurg Sci 44:89-93

45. Tirakotai W, Schulte DM, Bauer BL, Bertalanffy H, Hellwig D (2004) Neuroendoscopic surgery of intracranial cysts in adults. Childs Nerv Syst 20:842-851

46. Turtz AR, Hughes WB, Goldman HW Endoscopic treatment of a symptomatic pineal cyst: technical case report.Neurosurgery37:1013-1014; discussion 1014-1015, 1995

47. Vaquero J, Martinez R, Escandon J, Bravo G (1988) Symptomatic glial cysts of the pineal gland. Surg Neurol 30:468470

48. Weimer K, Gulewitsch MD, Schlarb AA, Schwille-Kiuntke J, Klosterhalfen S, Enck P (2013) Placebo effects in children: a review. Pediatr Res 74:96-102

49. Wisoff JH, Epstein F (1992) Surgical management of symptomatic pineal cysts. J Neurosurg 77:896-900

50. Yoshimoto K, Araki Y, Amano T, Matsumoto K, Nakamizo A, Sasaki T (2013) Clinical features and pathophysiological mechanism of the hemianoptic complication after the occipital transtentorial approach. Clin Neurol Neurosurg 115:1250-1256

51. Zhao W, Zhu DM, Zhang Y, Zhang C, Wang Y, Yang Y et al (2019) Pineal gland abnormality in major depressive disorder. Psychiatry Res Neuroimaging 289:13-17

\section{Figures}



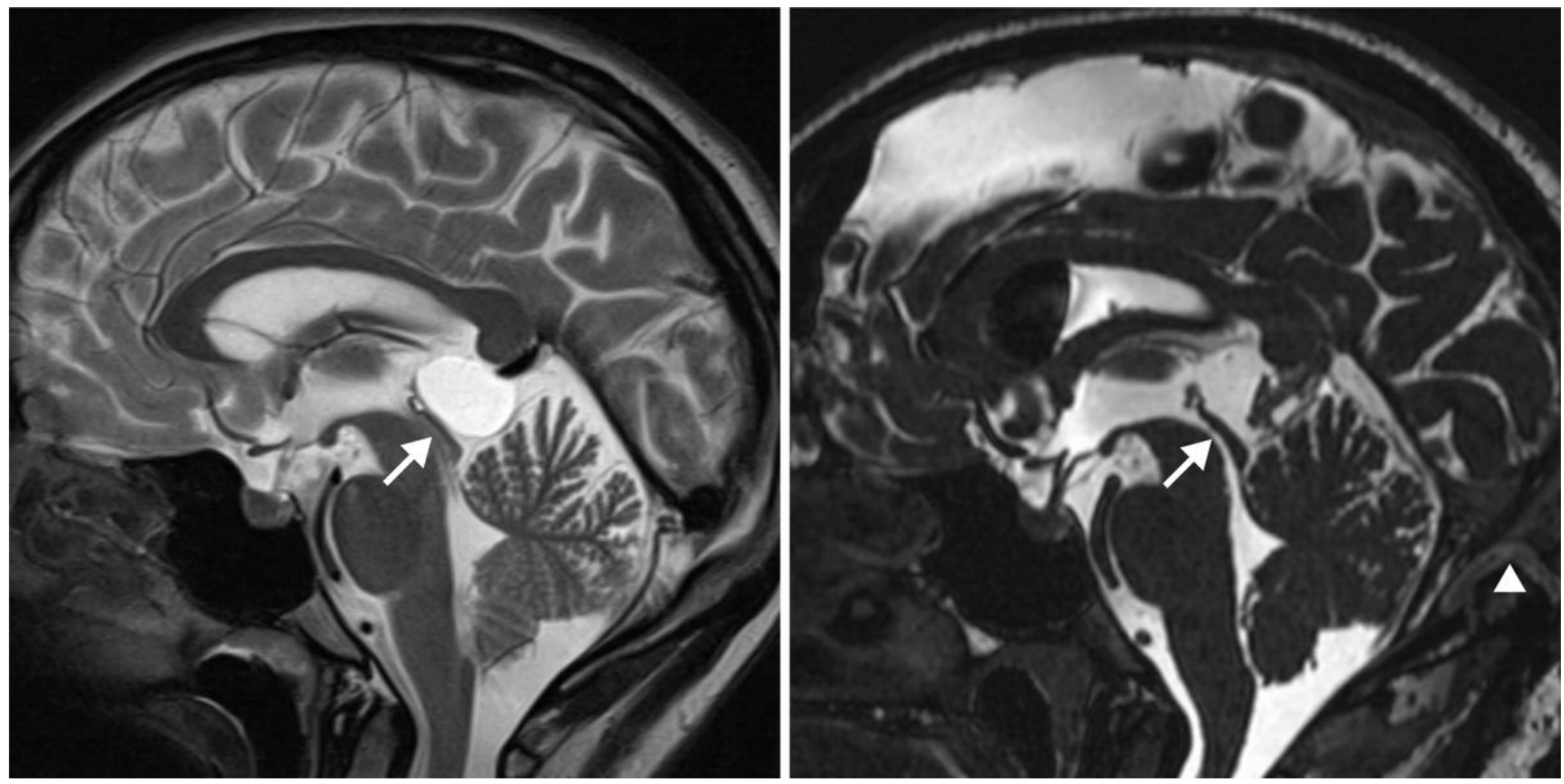

\section{Figure 1}

Midsagittal MR CISS before (A) and after surgery. demonstrating a pineal cyst leading to a narrowed Sylvian aqueduct (arrow) without hydrocephalus. Patient complaining of longstanding and increasing headache attacks.

Post-operative MR CISS (B) midsagittal image: complete cyst resection; open Sylvian aqueduct. Craniotomy reaching the transverse sinus (arrow-head). Symptoms resolved completely. 


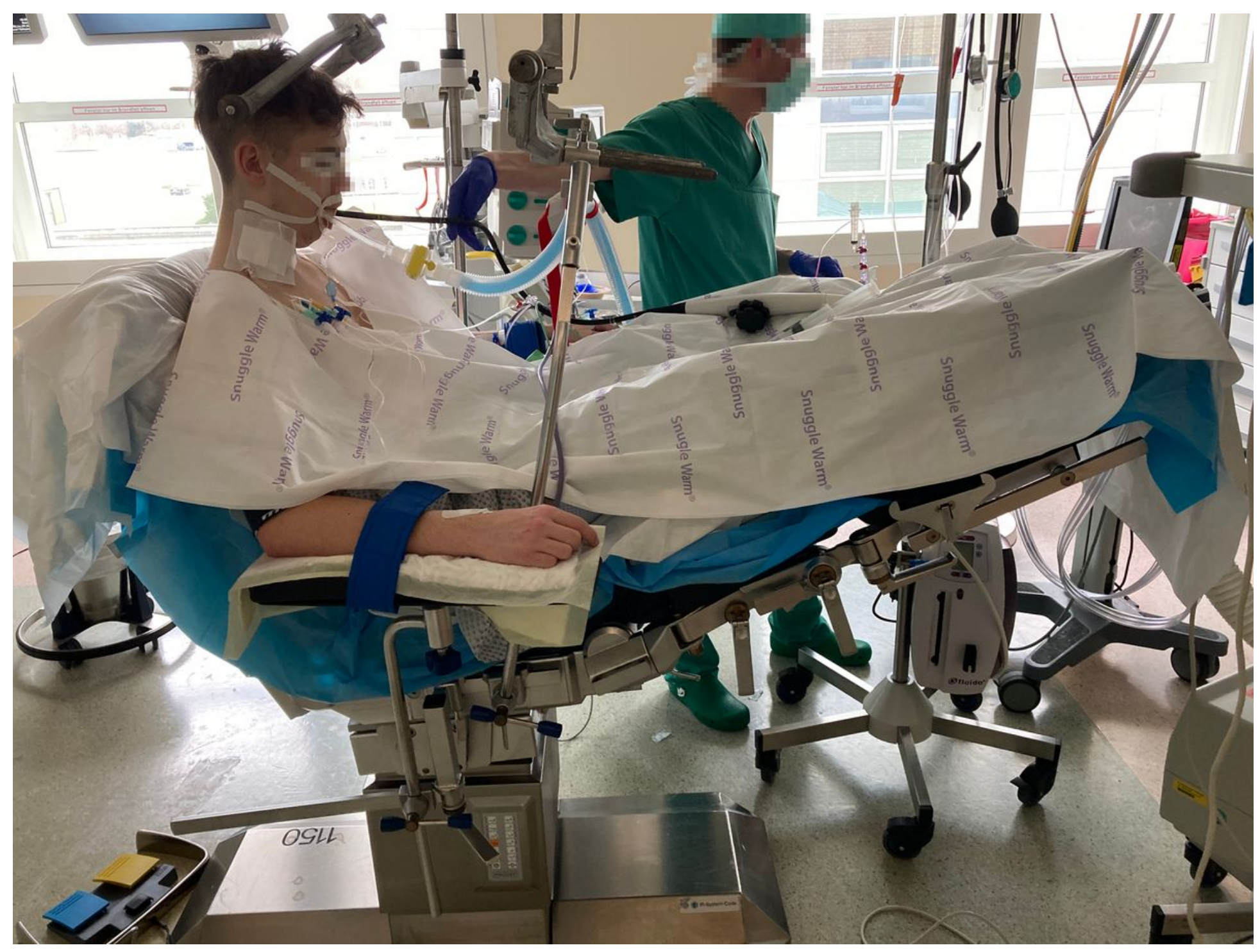

Figure 2

semi-sitting position
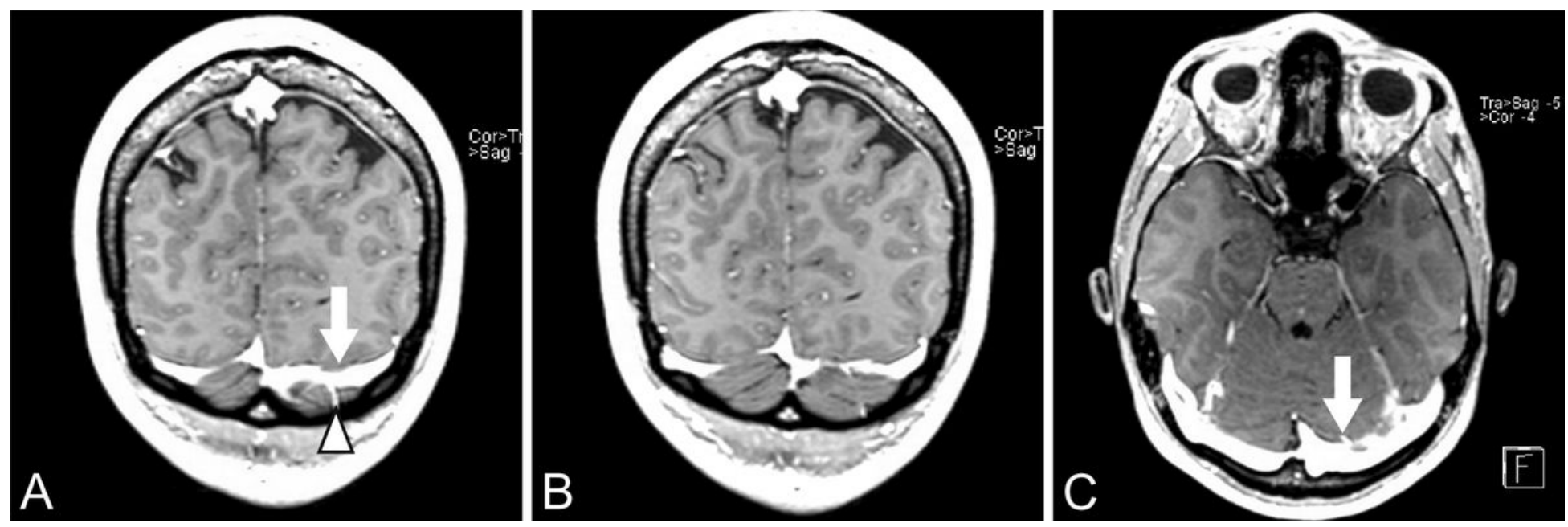

Figure 3 
contrast-enhanced T1 weighted MR (coronal $(\mathrm{a}, \mathrm{b})$ ) (axial (c)): left-sided predominant sinus and bridging vein; decision for approach on right side with the higher-rising sinus
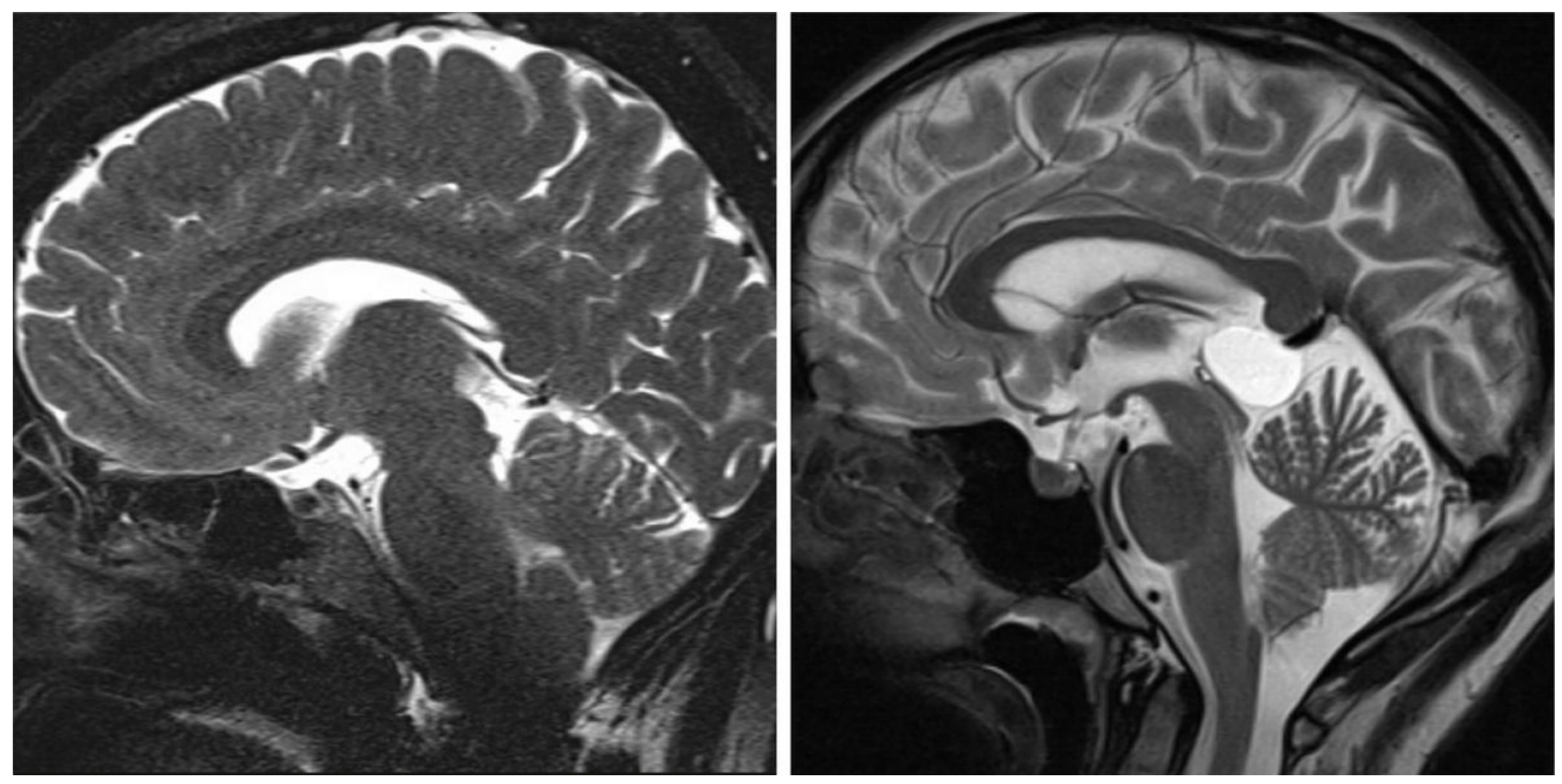

\section{Figure 4}

variations of steepness of tent: paramedian (a) viewing trajectory to the pineal region is not as steep as in the midline (b) approach 


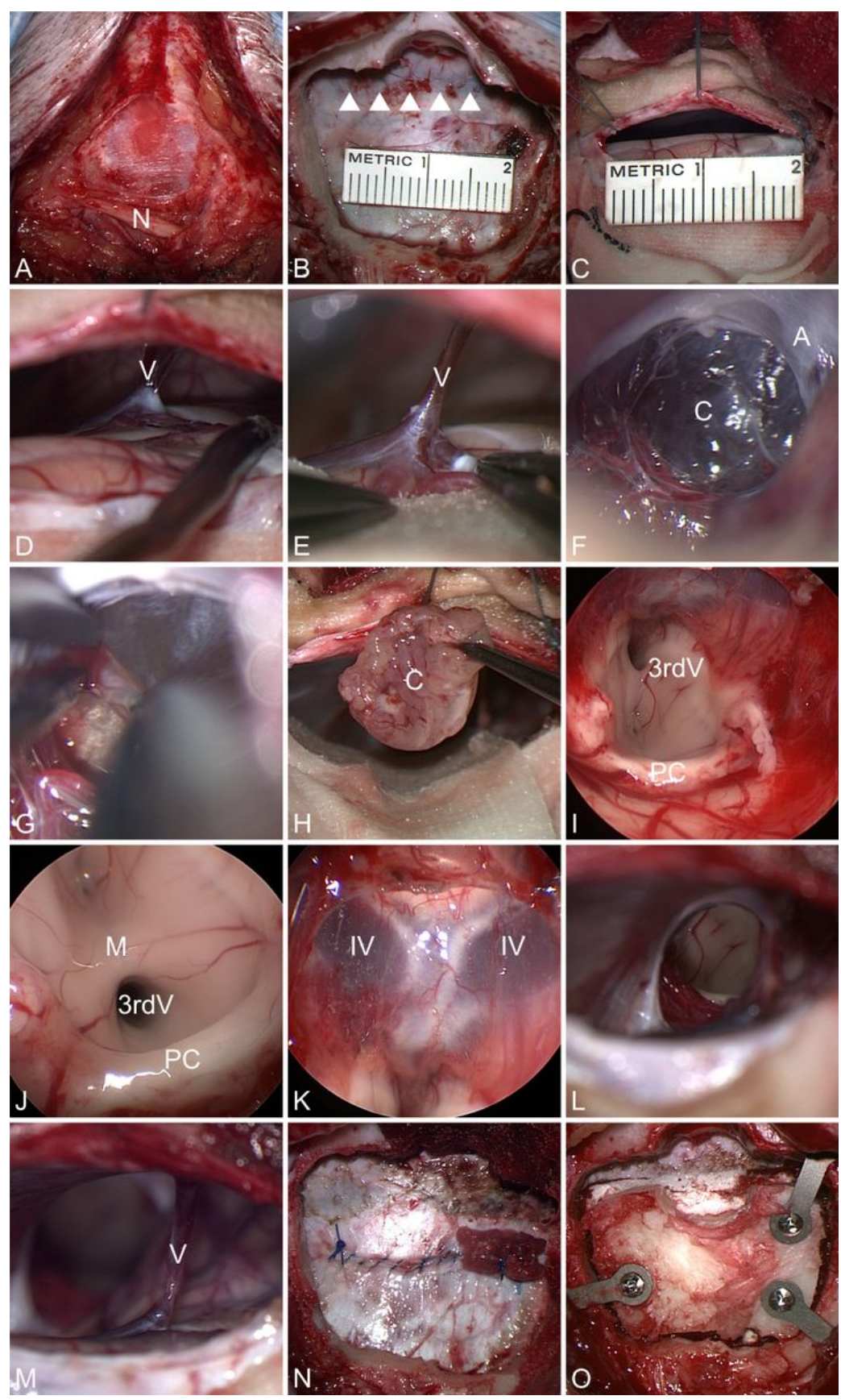

\section{Figure 5}

A: skin incision; greater occipital nerve $(\mathrm{N})$

B: craniotomy exposing the transverse sinus

C: dural incision alongside the transverse sinus

D and E: dissection of bridging vein (V)

F: pineal cyst (C) surrounded by thick arachnoid (A)

G: bimanual dissection

$\mathrm{H}$ : resected pineal cyst (C) 
$\mathbf{I}+\mathbf{J}$ endoscopic view into the third ventricle showing massa intermedia (M) and posterior commissure (PC)

$\mathrm{K}$ : endoscopic view to the roof of the third ventricle with a $45^{\circ}$ endoscope shows the large internal cerebral veins (IV)

L: microscopic view of the resection cavity showing gross total cyst resection

M: preservation of the bridging vein after cyst removal

$\mathbf{N}$ : dural closure

0: bone flap fixation with miniplates 